\section{Case Studies On Domestic Servants: Reflections On Rural Poverty ${ }^{1}$}

\author{
- Saubhagya Shah ${ }^{2}$
}

\section{Introduction}

This is a descriptive paper that attempts to explore the working and living conditions of child (under 15 years of age) Kaamgarnes (domestic servants) in a lower middle class neighborhood in the city of Kathmandu Since the condition of being a child servant is not generally of one's volition but rather a desperate survival mechanism, this paper will also link the chronic rural poverty with the continuous and growing use of child labour, particularly among Nepal's urban middle class households.

1. A Part of this paper was presented at the First National Congress 'Structure and Transition: Socieil', Poverty and Politics in Nepal" organized by the Sociological/Anthropological Society of Nepal (SASON), Kathmandu, Sept. 4-6, 1992.

2 Assistant Lecturer at the Central Department of Sociology/Anthropology. T. U. Kirtipur.
The work is divided into six units. The brief introduction will be followed by a discussion of the methodology employed for the study. The third chapter seeks to portray a picture of rural peasant poverty in Nepal with the use of existing statistical indicators. That is followed by three selected case studies. The last unit draws conclusions from the case studies and makes tentative inferences on the causes and implications of poverty for the domestic servants.

\section{Methodology}

This study utilizes the case study method in order io gain a more qualitative insight into the daily life and labour of Kaamgarne children. Without in any way undermining the significance of the quantitative method, the primary focus on the case study method for this particular study lies in the author's desire to escape from some of the obvious limitations of statistics and portray the human side of poverty that is often lost in an over-relience on numbers. As Oscar Lewis stated in his book Five Families, "Not all aspects of the human being can be studied statistically". The case study method, with its focus on everyday events and interactions, is a very appropriate technique that can complement quantitative findings. This method explores the unique experiences of individuals, in this case the Kaamgarne children, and providies qualitative insight into the actual working and living condition of the servants. Such understanding, it is hoped, can lead to a better appreciation of the poverty scenario as opposed to those that rely solely upon quantitative indicators that may miss the "trees for the forest".

The present case studies are the product of the author's six months of residence in Ward No. 22 of Kathmandu Municipality during 1991-92. The author lived in a rented room in the same house as the subject of case study no. 3 and the other two case study subjects worked in adjoining houses. The 
case studies are basically constructed from first-hand observation, informal discussions with the Kaamgarne (who were quite shy in the beginning), their Sahus or Maliks (masters who were outright suspicious at first) and the guardians and parents of the child workers themselves.

During the stay in the locality, the author became acquainted with several residents in that area and was able to observe the Kaamgarnes in those families during social visits. Although twelve Kaamgarne Children became quite well known to the author, only three are represented here due to space constraints and also because the three particular masters were relatively open and helpful in answerirg the research questions. On the express request of these masters, the first name of the Kaamgarne children has been altered to maintain anonymity.

\section{Overview on Nepalese Rural Poverty}

As an overwhelmingly agrarian country with over 93 percent (Unicef, 1992: XII) of the economically active population engaged in agriculture related occupations, land in Nepal is necessarily the major form of economic wealth and sociopolitical power and prestige. Currently 26 percent of Nepal's total landmass of $147,000 \mathrm{~km}^{2}$ is under cultivation and 43 percent of the agricultural land lies in the Terai while 48 percent falls in the Midhills, the rest lying in the Mountain zone. A mere 21 percent of the total cultivable land is irrigated and there is very little mechanization in agricultural production (Unicef 1987: 27). All of these factoss ensure one on the lowest per unit area productivity in South Asia. Productivity generally exists at a subsistence level and the actual per hectare yield for rice, maize, barley and millet has been gradually declining in the Nepalese midhills during the period 1971-1981 (Unicef 1987: 31).

Not only are there great technological and ecological constraints but the socio economic structure also hinders greater productivity in agriculture. The top 6 percent of the land holding families still control 44 percent of all cultivable lands while the bottom 94 percent of the households own the remaining 56 percent (Sainju, 1988:83) despite various efforts undertaken by the state for a more equitable distribution. The extreme nature of economic inequality is similarly attested by the fact that the wealthiest 10 percent of the people earn 47 per cent of the total income while the poorest 40 percent receive only nine percent (Unicef, 1987: 16)

There are nearly 2 million farm households in the country and an average household owns 1.13 ha. (CBS, 1991: 61 ) of land. Nearly 50 percent of all the holdings are less than 0.5 ha. in size which is insufficient to cover the food needs of an average family of five to six Members (Unicef, 1087: 28).

According to government figures, 42.5 percent of all Nepalese fall below the officially defined poverty line assessed at Rs. 10,667 (US dollar 500) per family per year where the national per capita income is US $\$ 170$ per year (Unicef, 1987: 16). However, a recent World Bank report estimates that more than 70 percent may fall below this poverty line (Unicef, 1992: 1). A significant proportion of peasant families are unable to grow suffieient food to feed their families for all twelve months. As a result nearly 50 percent of all children under age five group suffer from malnutrition and 78 percent of all women suffer iron deficiency anaemia (Unicef, 1991: 19). The poverty situation is further aggravated by the fact that more than 60 per cent of the rural population is illiterate (CBS, 2048-49: 2). Of the 64 percent who enroll in primary school, a mere 27 per cent are able to complete the level due to complex set of socio-cultural factors (Unicef, 1991: 13).

Out of necessity a majority of peasant families are forced to supplement their meager yield from their landholdings by either portering, working as agricultural labourer, 
construction workers or in a variety of other manual and unskilled labour. Likewise, as a survival strategy, a large number also migrate both within and outside the country in search of economic opportunities (Unicef, 1987: 9). The 1981 census recorded 187,795 people absent from households (but remained within the country) and most of them had left for finding work as agricultural labourer, and other manual employment. However, a even larger number, 402,977, had gone outside the country, mostly India, to find labouring and other service work (CBS, 1991: 16)

Abject poverty, gradually shrinking landholdings, declining productivity and a general lack of socio-economic opportunities in the midhills has been forcing lakhs of people to immigrate into relatively unpopulated areas of Assam, Nagaland, Mizoram in India and also into Bhutan and Sikkim since the 18 th century. Similarly, hundreds of thousands of people go to India for seasonal manual labour work as coolies, construction workers and labourers. Others may stay there for longer periods and work in factories or as the ubiquitous Darwan (watchmen).

Foreign armed forces is another avenue for hill people seeking better opportunities. Made notorious by the name Gurkha, currently there are estimated to be at least 150 thousand Nepali men in the Indian Army, policy and paramilitary forces such as the Border Security Force, Inda Tibetan Border Police, Assam Rifles etc. However, the exact number of Nepali in foreign armies is usually not disclosed due to "security reasons." Another couple of thousands are employed in the British Army and Singapure Police. Recently, the expanding economies of South Korea, Taiwan, Japan and the construction boom in the Gulf countries is also attracting a large number of Nepali manual labourers.

The women and the girls have also been forced to followed their menfolk abroad in an attempt to escape the vicious cycle of poverty, but with a difference. While their men sell their labour, the women are compelled to sell their bodies. Currently, it is estimated that there are no less than 153,000 Nepali girls forced into prostitution in India. (CWIN, 1992: 16). Annually 5-7 thousand girls aged 10-14 from the Nepali hills are sold to brothels in cities like Bombay Delhi and Calcutta (Unicef, 1991: 21). Delhi alone is estimated to have 18,000 Nepali child labourers and 30,000 girls under the age of 16 working in brothels (Banskota, 1992: 10). The poverty at homes compels young children to move from villages to urban centres and from the hills to the Terai The number of such migrant Kaamgarne children was estimated to be around 45,000 in 1988 in Kathmandu alone (Sainju, 1988: 83). In overall terms, it is estimated that over 4.5 Million Children or nearly 60 percent of the under 15 age group contributes labour with a typical work day of upto 15 working hours (CWIN, 1988: 160). Invariably it is these children who will miss out school or other trainings. The harsh reality of poverty takes an especially heavy toll on children, the poorest of the poor and the most vulnerable among the weak. From around age five their labour is used, sold or exploited depending upon their condition and the nature of the contract.

\section{Case Studies}

\section{Case Study - One}

As one enters the brown three storied house through the metal door. one invariably sees a little girl crouching over a pile of dirty dishes - deligently scrubbing and rinsing the pressure cookers, pots, pans and plates. The cement landing with a water tap under the stair case is where Rupa Sharma, the family Kaamgarne Ketee ( $g i r l)$ does most of her work, cleaning dishes, washing clothes and filling and ferrying water jars to the kitchen on the top floor.

The dimple cheeked Rupa has been working for this 
middle class family in ward 22 for the past one year, although it is not the first family she has worked for. Earlier she worked for a foreign merchant family for some fifteen days, but quit after they made her "sleep on the cold floor". She was brought to work in Kathmandu from her home in Kavre district by her maternal grandmother. Grandmother herself has been working for some years at the housa of Rupa's Malik's (master's) Salee (Sister-in-law). Asked why she had to come to Kathmandu, "Gharma Khana Pugena" (there wasn't enough to eat at home) Rupa says shyly. After separating from his father and two brothers, Rupa's father ended up with 8 Ropani ${ }^{-0}$ of Pakho (unirrigated/dry land) and 1 Ropani of Khet (irrigated paddy field) from the ancestral property. The 28 year old man and his wife, 25 , till the land but the yield is insufficient to feed the four daughters and one son. "Muskil le saat mahina chalchha" (hardly lasts seven months), Ram Prasad says. During the agriculture off season, he tries to supplement his income by working as a cook, contruction labourer or porter in Kathmandu; Rupa's other Bahini (younger sister) Sita works as a servant in Rupa's employer's younger salee's house in Butwal. The other two younger sisters help their parents and tend the few heads of cattle and goats, the youngest son is too small to help yet.

For her age, Rupa has a busy schedule. She must get up around six in the morning, otherwise she will be late for the morning milk queue. She then makes 'bed tea' and wakes her master's family of three with steaming cups of tea. Soon it's time to clean and carry water from the tap on the landing. On most mornings, Rupa then makes a second trip to the bazaar to purchase vegetables, rice or other items. Upon return, She cuts vegetables, picks out chaff and rocks from the rice and starts cooking for the master who has to leave by 9:30 for work. She also has to ensure that a continuous supply of boiled water is available. She now turns into a efficient waitress, serving the

- Approximately 20 Ropanis to a hectare. meal energitically to the family. When the family finishes eating their meal, another long bout with dishes commences for Rupa at the scullery. Between numerous errands for her master and mistresses, she quickly gobbles her Dal Bhat (soup and rice) and puts on her coarse blue faded frock. She grabs her bag and rushes off to school around 11 A.M. which is 10 minutes walk away.

Attending school is the payment for her labour. When the 'negotiations' were made, Rupa's mother had insisted that she wanted no 'wage' for her daughter's service,-only that Rupa be sent to school as long as she wants to. Indeed, Rupa's parents get no money. Her two meals a day and may be some snack, two sets of clothing a year, some medicine when she is ill and the schooling is what Rupa earns of her labour.

Rupa is enrolled in class one and arthough primary education is officially supposed to be free, the school still charges Rs. 350 annually as registration fee. Additionally her master's spend about Rs. 30 monthly on her books, copies and pencils. The primary reason why her patents decided to send her to work in Kathmandu was simple economics - it would mean one less month to feed and secondly, because they couldn't afford her school expense in their own village school.

Rupa, who looks rather small for her 11 years is quite intelligent. Her teacher says she works hard, but she failed her maths in the quarterly exams. She tries to fit in her homework and study sessions when there is a relative lull in her numerous errands and tasks placed on her and when she can find a quite corner in the house. But her study often is cut short when any of the family members ask her to bring a glass of water, make tea, rush to the market or do elrands in the neighbourhood. The school ends at 3:30 P. M. and Rupa gets back home, often tired and hungry. She may get some Khaja and tea, but she is taught not to ask many things and express her needs. There may be a brief rest for her now depending on 
Whether there are any guests at home or many errands to be done. Rupa's work load increases to the number and frequency of guest arrivals. Soon she has to make tea and then start cleaning dishes again. Some days she does laundry as well. Occasionally when there is no water in the tap, she must carry 10 litre pitchers of water from the tap ten blocks down the street.

Then the evening round commences for Rupa with a trip to the market again. She returns and starts with the Daal, Bhat; her mistress usually cooks the vegetables. She has to serve the food in the living room if someone decices to have dinner with the TV. When everyone has eaten (not everyone eats at the same time) and the dishes are taken care of, Rupa eats quietly alone. She then sweeps and scrubs the kitchen. By now it is nearly 10-10.30 P.M. Though she is often exhausted by this hour, she may not be able to go to bed if the family is watching late night TV programme. When the family retires to their beds, Rupa pulls out the bedding from beneath the sofa and spreads it on the floor and is soon fast asleep beneath the big TV cabinet, totally exhausted by the long day's labours.

And she gets no leave; seven days a week, four weeks a month. Rupa works. She goes home with her parents for a few days during Dashain, Tihal or Teej and Her father or mother come every 3 or 4 months to visit her. The mother especially is particular that Rupa should not miss school, that is why she does not insist on taking Rupa home often. Very infrequently, Rupa shows sings of home sickness, but if asked, she quickly says nothing is wrong.

She has to address her masters with the honorific 'hazur' and never talk back. She is also disciplined never to sit on the beds, chairs or sofa in the house-she usually curls up in an obscure corner of the house when there is no immediate work to be done. Asked one day alone what she hoped to do in the future 'I don't know what it will be' she said demurely adding 'but I must study haro'. It is to be seen how far her study - her mother's wish can go.

\section{Case Study - Two}

The thin boy with ill fitting clothes can be often seen absorbed with the Gorkhapatra or other vernacular weeklies at the neighbourhood newspaper stand. He couldn't be a schoolboy, his over sized clothes and his odd reading hours-during the mid day - betray that. Upon inquiry, it was found that this voracious reader, Gorae Giri (14 years old), was another Kaamgorne in a nearby middle class joint family. Gorae is originally from Jumla. His father died some five years ago and his mother passed away the next year. Of his three siblings, the Dai (elder brother), a deaf mute, is a farm labour for a lancholding family in Bajura district and his Didi (elder sister) is married and has children in Jumla Gorae's Bhai (younger brother) was brought to Kathmandu as a Kamgarne by a civil servant who had been posted in Jumla. Even after working in Kathmandu for some three years, Gorae has not met his younger brother who came to Kathmandu a year earlier. He has, however heard that his Bhai is well taken care of and even sent to school.

Gorae's siblings had started working as Kaamgarnes and hired helps in their native village when their parents were alive; usually washing dishes, fetching firewcod, or tending cattle. Gorae's father had drifted to Jumla from Palpa with nothing, he made his living by selling firewood in the district headquarter. It got especially hard for the father to make ends meet without any landed property or kinship support when he started a family with a local girl. After the father died, Gorae worked for the local Pradhan Pancha for a year but when his mother died next year, he moved to a teacher's house who encouraged him to continue schooling. However. after the fifth grade, Gorae decided to quite school, he says he was "ashamed of his servant status among his class mates", 
Some three years ago, the teacher for whom Gorae worked, decided to send Gorae to her sister who was married and lived in Kathmandu. As a domestic servant in Kathmandu, Gorae has a long day. $\mathrm{He}$ is usually up by $5.30 \mathrm{~A}$. M., making and serving the "bed tea". Gorae's master, who works as a junior officer in a large hotel and the wife works for a bank, also have a older Kaamgarne boy. Between the two of them, Gorae and his colleague sweep the floor, fetch water from the community tap, and purchase groceries. As both the master and his wife work in offices, the morning meals have to be ready early. When everybody in the family has eaten. the two boys get to eat. After the meals, the kitchen has to be cleaned and the pile of dishes washed. Later, there are usually some clothes to be washed and ironed.

Around noon the boys are done with their morning chores. Gorae's partner goes out for a few hours to a carpenter's shop to do apprenticeship. It is during this time that Gorae runs off to the nearby news stall where he can read a paper for 15 paisa each He doesn't get any salary or wages for his labour, but he does get some spending money every now and then (not more than Rs, 40 a month). He spends most of this money at the newspaper stand. He reads on almost any topic, his recent craze is the Thai Airbus accident. He was particularly worried that they hadn't found the black box.

Besides the small pocket money, Gorae gets clothing, some medicine when he is sick, and of course, meals and some snacks However, he has been promised that when he gets "thulo" (older), he will be provided with a salaried employment somewhere (Nep Jagir Milaideene). His master offered to have him enrolled in a school, but supposedly Gorae refused that. For Gorae, the future consists of the day when he will have his 'Jagir'. Recently, he has been talking about joining the army. He somedays goes to watch the parades at the army grounds at Tundikhel.
-The traumas of his family tragedy has given him a sad looking appearance. Moreover, a childhood spent as a domestic servant has made him shy and reclusive boy. Unless required, he avoids other people and makes minimum conversation. His masters 'train' him not to express emotions or feelings and he is encouraged to be obedient and detached. Gorae is constantly made aware of his inferior position in the household; he must not sit with his masters, he must address them with honorific 'Hazur', and be spoken in turn to with the lowly 'Tah'. Asked how he felt about his work in Kathmandu, "Jahan gayepani karma ma dukha lekheko chha" (Where ever I go, I'm destined to suffer) he said in a pained voice.

Around 4 ' $O$ ' clock its time to make tea and 'Khaja' for the family. The people from the offices return. After cleaning the dishes, Gorae usually goes to the market for vegetables and other supplies. The evening meal is readied by $8 \mathrm{PM}$, the family womenfolk may also help with some of the cooking. The family eats by 8.30 PM. and the two Kaamgarne boys start doing the dirty diseas and cleaning the kitchen. Gorae is lucky there is another person to share the drudgery. When the evening round is completed, Gorae usually goes to watch the TV. The world news interests him and so does sports. The two 'Kaamgarne' then go to sleep on the floor on the 'Matan' (space outside the kitchen).

\section{Case Study - Three}

For her tender 10 years Kamala Thapa Magar has undergone a lot. When she was only 7 years old Kamala's mother ran away from the first husband and settled with a new man, her fufu's (father's sister) son. Kamala and two younger brothers also came with the mother. However' the step father wasn't as kind as he could be and made life difficult for the three children, especially Kamala.

Kamala has now been employed as a Kamgarne in a middle-level travel officer's house. Earlier, it had been arranged 
to pay her Rs. 60 per month, but 5 months ago hep employees hired another Tharu girl from Bardiya. Subsequently her salary was reduced to Rs. 50 a month reasoning that her work load would be reduced with another servant sharing the work. The two girls work together from early morning sweeping the house, washing dishes, purchasing groceries and cooking. After the family has eaten and the master has gone for work, the girls usually have to do some laundry. Afterwards they have a few hours of rest during the afternoon. The girls usually spend the afternoon break either resting or talking with the other neighbourhood Kaamgarnes.

The evening work shift begins around 3.30. Kamala has to go to the nearby school bus stop to receive the family's children returning from school. The children usually dump the oversized bag; and lunch boxes on to Kamala on the way back as they do when she walks them to the bus stop in the morning. One of the school boy is aged 10 and his 5 -year old sister is in nursery classe. Kamala had also gone to school for $\mathbf{3}$ years in Tistung, but she was unable to continue. Now it is most ironic to observe her lugging two heavy bags of books to and from the school bus when she probably will never have an opportunity to study herself.

This is not Kamala's first job. Before coming as a servent here she worked for 19 months weaving carpets in a factory in Jawalakhel. The inadequate nutrition, unhealthy work-

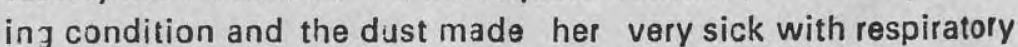
problems. She was forced to quit that work and stay with her fufu who has been working as a servant for Kamala's master's Jethan (brother-in-law) for 14 years. The fufu promotly arranged for Kamala to work in the present place thinking that the work in a house would not be nearly as streneous as carpet weaving.

Kamala's mother tends the three younger sons and looks after the moager land holding in Tistung. Makawanpur district. The produce from the land is insufficient to feed the family, much less pay the Rs. 8,000 debt. the family incurred when the mother got sick two years ago during the birth of her last son from her now husband. Now Kamala's father works in Kathmandu as a porter, truck loader or a pushcart n'alla depending upon which job is available $O n$ an average day he makes anywhere between Rs. 35 to 70 , provided he can find work. $\mathrm{He}$ goes back to Tistung during planting and harvesting season to help his wife manage the agricultural work. "Even with so much sweat and labour. I still can't properly feed the children" said 31 year old Kamala's father while taking a break from cement loading job at Kalimati. Last week, Kamala went to her home for a few days' visit. Her masters have now learnt that she won't be coming back to work for them anymore. Her parents have decided, now that Kamala feels a little better. She should work again at the carpet factory because it brings more money than a domestic servant. The masters feel betrayed by an ungrateful street bum to whom they had baen very "kind and generous'. Affer all, hadn't they fed her, clothed her and most of all - bought her a golden Fuli (ornament worn on the nose) from Kamala's six months' savings?

\section{Discussions}

One way or the other these three case studies can be linked with the pervasive poverty in the midhills of Nepal. The two children in the case studies, Rupa and Kamala were from families that owned less than average sized land holdings. Gorae's parents were landless, never owning a house, much less land Rupa and Kamala's families are able to produce sufficient food for about six months, while Gorae's parents, when they were alive, had to meet all their costs of living through the sale of firewood and their own labouring. Low yield from agriculture, insufficient earnings make day to day survival difficult for these families. Like Rupa's father Ram Prasad says "Aik chhak ramro sanga khana pani garo parchiha" (it's hard to eat one meal regularly). The extremely small land holdings coupled 
with declining soil fertility and accelerating soil erosion is making it increasingly difficult for peasants like Rupa and Kamala's families to make ends meet even at the bare subsistence level. To eke out an existence for themselves, they are compelled to seek seasonal and temporary labour service elsewhere, even the children.

For example take the case of Rupa's father, while the mother takes care of the children and home, the father comes to Kathmandu when there is no agricultural works at home and works as either a construction labourer carrying bricks and cement or as a cook at an orphanage near Pashupati. Obviously, this alone does not provide enough food and schooling for this Brahmin family. Admittedly, education is a strong values for Rupa's parents, especially the mother even through both of them are illiterate themselves. As a consequence the parents have sent their two eldest daughters to work as domestic servants, so that they may get some schooling which they can't afford to give themselves. Kamala's case is more or less similar, coming from a step father's house who is heavely in debt and unable to feed the family most of the year, she had to first work as a carpet weaver at age eight and when her health failed, she worked as a Kaamgarne for a family.

Gorae's Case is the most extreme. Never owning any fixed assets like land or house, his parents lived practically on the toil of their day to day wages, there never was any saving to fall back on. Once they got ill and unable to work, the food also began to dry up. Not only did Gorae's parents not receive any medicine but they got insufficient food during their illness which hastened their premature death Once they died, the children were one by one picked up by people looking for 'Kaamgarne'.

The economics of Kaamgarne keta and keti looks exploitative. For two meals a day (which is often the left over from the master's ating) two or three pairs of clothes (which can often be the hand-me-downs of the master's children) and occasionally, a monthly salary of Rs. 60 or less, the children are made to labour long hours. A CWIN survey conducted on child labour in Kathmandu has also come up with similar findings regarding the pay and renumeration (CWIN, 1992: 11). Of course this doesn't apply to Rupa and Gorae, the former gets schooling and latter gets some pocket money instead of regular wage. In return, the children usually put in at least 8-10 hours of labour from 5-6 in the morning till late at night, seven days a week. Considering that the minimum starting salary for government peons has been set at Rs. 1,100 for 7 hours a day 6 -days a week work, what the children get or the masters make out of the arrangement does seem unjust. In this case acute poverty creates conditions where the bargaining position of the children or their parents is practically non existent. When this point is mentioned, the sahujees or maliks usually retort that the Kamgarnes are getting a much better deal than had they been with their families in the villages. As one master with two child nokers (servant) said, "here they at least don't have to worry about getting two regular meals a day and some money on the side". Others argue that the Kamgarne child doesn't have do the same amount of strenuous physical labour like in the village, such as firewood and fodder collection, agricultural work, etc.

As for the parents of the Kaamgarne children, they are resigned to their children working out of necessity. As far as immediate household necds go, it's one less mouth to feed and if it is a better deal the child would bring in some cash, however small, and education in the case of people like Rupa. It is a bare survival strategy for the poor. "At least the children get to eat and go to school" says Rupa's mother sadly when inquired how she felt about both her daughter workings far from home.

But there is more to it than the stark economics of child labour. A host of socio-cultural issues are involved. From 
his/her early formative age, the child Kaamgarne is strictly trained to be deferential and subservient to the master's family. The socialization is achieved through various ways; the servant has to address his masters with the honorific terms ' $H$ azur' and 'Tapain'; he/she must never sit on the bed/sofa/chair or rugs of his masters and in turn the 'Kaamgarne' will be addressed by the lowly term 'Tah'.

The attitude of superiority and inferiority are also reinforced by other processes For example, the Kaamgarne children almost invariably eat last when all the family has eaten. The children were also conditioned to be impersonal in the master's house, they are discouraged from showing any love, effection or sentiment. When Kamala's mother visits her daughter, Kamala looks ackwardly at her mother and doesn't know what to do-almost filled with guilt while the masters are present. But one day I spied her sitting on her mother's lap alone in the kitchen. While the mother combed and tended her hair, Kamala was whining and hugging her mother, being a real child, but when she saw me watching she stood up with a guilty expression. In extreme cases, the Kaamgarne chi!d may be depersonalized, viewed more as a functional work unit than a person. A few masters even frankly admitted that a servant in the home enhances the social standing, rather like a status symbol giving the image of wealth. Among middle class families who can keep Kaamgarnes, young children, especially girls are preferred for a number of obvious reasons; a study carried out by Rupa Dhital for CWIN on child workers in Kathmandu gives the boy girl ratio as 1:9 and sexual abuses are also reported against female child servants. (VO W, 1991: 21). First, the young child can be physically controlled more thoroughly, there is no fear of insubordination to threaten the master's power. Secondly, small child servants occupy less space to sleep, need less amount of clothing and eat much less. Of course they need to be paid very little as well. And when they can be had "for the price of two star beers" as one malik of a girl servant said, they definitely are within the affordability range for many.

The condition of being a child Kaamgarne in most cases not only mentally subjugates and expropriates the childhood of the kids, but it also effectively precludes other better opportunities and growth for the future. Because a servant develops no marketable skills, he/she will probably remain a servant for life thus perpetuating the cycles of poverty. As attested by the case studies, a network of servitude and client relationships evolve. Not only does a person remain a servant all his/her life, but will probably also induct their near relatives into the domestic servant network like Rupa's and Kamala's grandmother and fufu diJ. In many cases, it is also likely for servants from the same family or area to work for the some master or his kin group for generations. Therefore, the problem of poverty seems to be not only intragenerational but also intergenerational for lack of viable opportunity at socialmobility.

It is indeed few fortunate Kaamgarnes who can find time, encouragement and the will to get education or acquire skills after their long work hours. Since the pay is paltry, there is noquestion either of saving enough and starting one's own business' or farm. Even if the child, like Kamala, quits one master he/she will probably continue with similar menial works; restaurant dish washer, porter, construction worker or carpet weaver. For those without the minimum education or other skills it is hard to break out from the cycle of hard labour and poverty. This constriction of opportunities naturally breeds fatalistic outlooks. Even at such imaginative age, Rupa and Gorae have begun expressing such outlooks as "I don't know what will happen". "it's in God hands" or Kamala saying with a bit of sarcasm "life will pass scrubbing dishes" about her future. They are already "submerged in the culture of silence", to quote Paulo Freire (Freire 1982; 11). 


\section{Reflections}

Though limited in scope, these three case studies show several important lessons about developments in Nepal today, particularly with respect to children. Foremost, increasing the overall life chances of children as well as many other valnerable sectors of Nepali society may entail substantial restructuring of current Nepali socio-economic relations. Egalitarian relationships that secure and protect the intrests of all - instead of only the most powerful - will lead to a more equitable distribution of Nepals's limited resources; this, in turn, will lessen the pervasive poveriy that forces children into labour, prostitution, etc., or at the very least, into illiteracy, disease and the like. Anything short of such socio economic trasformation will only gave the appearance of development instead of attacking the roots of the problem.

\section{Reference:}

Banskota, Amrita; 1991. 'Bal Majdoor Samasya: Samadhan Kahile Hola ?'" Madhuparka (Nep.) Vol. 25, No. 4, Kathmandu.

CBS, 1992.

Four Manthly Statistical Bulletin, Vol. 3, 2048/49 Chaitra-Ashad.

CBS, 1991 .

Statistical Year Book, Kathmandu.

CBS, 1992.

CWIN, 1992.

CWIN, 1988.

Freire, Paulo; 1982

Nepal In Figures, Kathmandu.

$B_{a} /$ Sarokar (Nep.), Kathmandu.

Working Children In South Asia: Realities And Challenges. Seminar Workshop Procedings, Kathmandu.

Pedagogy Of The Oppressed.
Hirway, Indira (Et, al, Eds); 1991.

Towards Eradication of Child Labour:Oxford \& IBH Publishing, New Delhi.

Singh, I. S.; 1992.

Unicef, 1987.

Unicef, 1991.

Unicef, 1992.
Child Labour: Oxford \& IBH Publishing, New Delhi.

Children And Women Of Nepal: A Situational Analysis, Kathmandu.

The Situation of Children In Nepal, Kathmandu.

Children And Women of Nepal, Kathmandu. Continuum, Now York. 